\title{
The procoagulant effects of fine particulate matter in vivo
}

\author{
Evren Kilinç ${ }^{1 * \dagger}$, Holger Schulz $z^{2,4^{*}+}$, Gerhardus JAJM Kuiper ${ }^{1}$, Henri MH Spronk ${ }^{1}$, Hugo ten Cate ${ }^{1}$, \\ Swapna Upadhyay ${ }^{7}$, Koustav Ganguly ${ }^{7}$, Tobias Stoeger ${ }^{4}$, Manuela Semmler-Bhenke ${ }^{4}$, Shinji Takenaka ${ }^{4}$, \\ Wolfgang G Kreyling ${ }^{4,6}$, Mike Pitz ${ }^{3}$, Peter Reitmeir ${ }^{5}$, Annette Peters ${ }^{3}$, Oliver Eickelberg ${ }^{4}$, H Erich Wichmann ${ }^{2,6}$
}

\begin{abstract}
Inhalation of fine particulate matter $(<2.5 \mu \mathrm{m}$; fine PM) has been shown to increase the risk for cardiovascular events. In this letter, we reappraise the role of tissue factor (TF) antigen and we also summarize changes in measured coagulation proteins in humans and rodents by other studies with fine PM. By considering all studies including ours, we conclude that monitoring the overall coagulation state by measuring capacity assays such as thrombin generation, and quantification of TF activity would be more suitable than determining single coagulation proteins (such as TF antigen) in order to better assess the systemic prothrombotic effects of fine PM.
\end{abstract}

\section{Blood coagulation markers and fine PM exposure studies}

Evren Kilinç, Gerhardus JAJM Kuiper, Henri MH Spronk, Hugo ten Cate

Earlier epidemiologic and experimental studies have shown that fine particulate matter $(<2.5 \mu \mathrm{m}$; fine PM) inhalation is associated with arterial and venous thrombosis, as well as an increased risk for cardiovascular death [1]. Several studies have addressed the possible mechanisms involved in PM-related arterial and venous thrombosis, although the recently published work by Emmerechts et al. could not establish a direct effect of intratracheal PM instillation on induction of venous thrombosis in mice [2]. Tissue factor (TF) is expressed in subendothelial cells upon injury, or on the surface of cells like monocytes, macrophages and neutrophils. A small amount of TF is necessary to form a complex with factor VIIa to produce thrombin via the extrinsic pathway of coagulation [3]. Since PM is also related to endothelial damage and

\footnotetext{
* Correspondence: e.kilinc@maastrichtuniversity.nl; schulz@helmholtzmuenchen.de

† Contributed equally

${ }^{1}$ Department of Internal Medicine, Laboratory for Clinical Thrombosis and Haemostasis, Cardiovascular Research Institute Maastricht, Maastricht University Medical Center, P.O. Box 616, UNS 50: Box 8, 6200 MD, Maastricht, The Netherlands

${ }^{2}$ Institute of Epidemiology I, Helmholtz Zentrum München, German Research Center for Environmental Health, Ingolstaedter Landstrasse 1, D85764, Neuherberg/Munich, Germany

Full list of author information is available at the end of the article
}

activation of platelets and macrophages upon short term in vivo exposure [1], the measurement of TF in blood may be considered as a marker of cell damage.

A recent publication in this journal, addressed the effects of ambient fine PM in spontaneously hypertensive rats (SHRs) following intratracheal instillation at varying concentrations. Surprisingly, an early decrease in lung specific tissue factor (TF) antigen was observed at 1 and 3 days post exposure, whereas plasminogen activator inhibitor-1 (PAI-1) was increased at 1 day post instillation of fine PM [4].

It is known that a small proportion of TF exerts prothrombotic effects and the inactive form of TF may not reflect TF activity [3]. Additionally, tissue factor pathway inhibitor (TFPI), the physiological inhibitor of TF, regulates TF activity. Therefore, the measurements of TF antigen in tissues do not necessarily reflect the functional capacity and integrity of TF. Overall, measuring TF activity could be a better approach for determining procoagulant activity in tissues (local effect) and plasma (systemic effect).

Indeed, we recently showed that short-term inhalation of fine PM increased lung specific TF activity at 4 and 48 hours post instillation as well as the overall procoagulant potential of lung tissue, as assessed by thrombin generation, most likely through attenuated expression and activity of the natural anticoagulant thrombomodulin [5].

In addition to rodent studies [6], different single coagulation proteins have also been measured in humans 
exposed to fine PM [7-11]. The outcome of such studies is rather inconsistent however, either with changes, or no change in the levels of coagulation proteins, such as factor VII (FVII), FVIII, FIX, FX. The specific responses being most likely related to differences in fine PM source and the dose used, as well as the time course of sample collection and the experimental setup. At the same time, it is likely that possible procoagulant reactions to acute PM exposure will be downplayed by an increased anticoagulant response as a systemic protective mechanism. Therefore, the balance in pro- and anticoagulant reactions to PM will modulate the net thrombotic events via thrombin, which is the critical enzyme regulating the final common pathway leading to fibrin formation [5].

In further studies of prothrombotic mechanisms of PM, either after acute or chronic exposure, we would advocate the use of overall capacity assays such as for thrombin generation, in conjunction with TF activity and specific anticoagulant proteins in order to better understand the net contribution of fine PM to thrombotic and cardiovascular events.

\section{Response to Kilinç et al}

Holger Schulz, Swapna Upadhyay, Koustav Ganguly, Tobias Stoeger, Manuela Semmler-Bhenke, Shinji Takenaka, Wolfgang G Kreyling, Mike Pitz, Peter Reitmeir, Annette Peters, Oliver Eickelberg, and H Erich Wichmann

We appreciate the comments from Kilinç and coworkers concerning application and interpretation of blood coagulation markers in PM exposure studies. They suggest the application of capacity assays rather than measurements of single coagulation factors to better understand alterations of the coagulation homeostasis in PM exposure studies. With respect to our study [4], the functional activity of TF in target organs would have been more suitable than measurement of the antigen level in tissues. We agree with Kilinç et al. that TF activity or even further coagulation assays would certainly improve our understanding of the complex response observed in our PM2.5 Augsburg (PM2.5-AB) exposure study. Reliable activity assays evaluated in correspondence to their protein/transcription levels always provide essential functional information of biological responses. However, our study was designed to get a global impression of PM2.5-AB associated inflammatory and cardiovascular effects in target organs and their potential interactions rather than being specifically focused on disturbances of the coagulation cascade. Related to thrombogenic effects reported after PM exposures $[6,10,12-16]$, we selected TF and PAI-1 as representative markers to assess deteriorations of the coagulation homeostasis. Increased levels of TF and PAI-1 were observed in the heart three days after exposure to high PM2.5-AB.
This is in line with the common understanding that inflammatory activity - as evidenced in our study by increased levels of osteopontin and macrophage inflammatory protein (MIP)2 in the heart and $\mathrm{C}$ - reactive protein (CRP) in the serum - triggers TF mediated coagulation [17]. The scenario observed in the lung appears to be more complex, an early inflammatory response at day 1 is associated with a reduced TF and an increased PAI-1 level while at day 3 both markers, in particular PAI-1, were substantially down regulated. Most inflammatory markers reached baseline levels at this time point [4]. Our data indicate that PM2.5- $\mathrm{AB}$ exposure alters the coagulation homeostasis in lungs and heart and shows that main target organs exhibit a different response with respect to time course and direction. As already mentioned by Kilinç et al. these results are principally in line with reports from other studies whereby differences in the PM source, the route of administration, and the dose may explain the different outcomes described so far with respect to the endpoints selected. Indeed, uncovering the underlying pathomechanisms of PM2.5-AB associated effects on the homeostasis of blood coagulation warrants further investigation and would require the assessment of platelet function, major pro- and anticoagulant pathways and may be even the bidirectional interaction between inflammation and coagulation [17]. It remains a task to specifically address this issue by assessing protein levels and functional activity for a set of key coagulation events including the assessment of the tissue factor thrombomodulin balance and fibrin formation as suggested by Kilinç et al.

\section{Acknowledgements and funding}

EK granted by the Netherlands Heart Foundation (grant number: 2006B064).

\section{Author details}

${ }^{1}$ Department of Internal Medicine, Laboratory for Clinical Thrombosis and Haemostasis, Cardiovascular Research Institute Maastricht, Maastricht University Medical Center, P.O. Box 616, UNS 50: Box 8, 6200 MD, Maastricht, The Netherlands. ${ }^{2}$ Institute of Epidemiology I, Helmholtz Zentrum München, German Research Center for Environmental Health, Ingolstaedter Landstrasse 1, D85764, Neuherberg/Munich, Germany. ${ }^{3}$ Institute of Epidemiology II, Helmholtz Zentrum München, German Research Center for Environmental Health, Ingolstaedter Landstrasse 1, D85764, Neuherberg/Munich, Germany. ${ }^{4}$ Comprehensive Pneumology Center, Institute of Lung Biology and Disease, Helmholtz Zentrum München, German Research Center for Environmental Health, Ingolstaedter Landstrasse 1, D85764, Neuherberg/Munich, Germany. ${ }^{5}$ Institute of Health Economics and Health Care Management, Helmholtz Zentrum München, German Research Center for Environmental Health, Ingolstaedter Landstrasse 1, D85764, Neuherberg/Munich, Germany. ${ }^{6}$ Focus Network Nanoparticles and Health, Helmholtz Zentrum München, German Research Center for Environmental Health, Ingolstaedter Landstrasse 1, D85764, Neuherberg/Munich, Germany. ${ }^{7}$ Department of Environmental and Occupational Health, Graduate School of Public Health, University of Pittsburgh, PA, Bridge Side Point; 100 Technology Drive, Pittsburgh, 15219 PA, USA.

\section{Authors' contributions}

EK, HS, GJAJMK, HMHS, HtC, SU, KG, TS, MSB, ST, WGK, MP, PR, AP, OE, HEW all equally contributed to writing this manuscript and approved the final version. 


\section{Competing interests}

The authors declare that they have no competing interests.

Received: 14 January 2011 Accepted: 15 March 2011

Published: 15 March 2011

\section{References}

1. Brook RD, Rajagopalan S, Pope CA, Brook JR, Bhatnagar A, Diez-Roux AV, Holguin F, Hong Y, Luepker RV, Mittleman MA, et al: Particulate matter air pollution and cardiovascular disease: An update to the scientific statement from the American Heart Association. Circulation 2010, 121(21):2331-2378.

2. Emmerechts J, Alfaro-Moreno E, Vanaudenaerde BM, Nemery B, Hoylaerts MF: Short-term exposure to particulate matter induces arterial but not venous thrombosis in healthy mice. J Thromb Haemost 2010, 8(12):2651-2661.

3. Breitenstein A, Tanner FC, Luscher TF: Tissue factor and cardiovascular disease: quo vadis? Circ J 2010, 74(1):3-12.

4. Upadhyay S, Ganguly K, Stoeger T, Semmler-Bhenke M, Takenaka S, Kreyling WG, Pitz M, Reitmeir P, Peters A, Eickelberg O, et al: Cardiovascular and inflammatory effects of intratracheally instilled ambient dust from Augsburg, Germany, in spontaneously hypertensive rats (SHRs). Part Fibre Toxicol 2010, 7:27.

5. Frederix K, Kooter IM, van Oerle R, Fens D, Hamulyak K, Gerlofs-Nijland ME, Ten Cate H, Spronk HM: A new method to determine tissue specific tissue factor thrombomodulin activities: endotoxin and particulate air pollution induced disbalance. Thromb J 2008, 6:14.

6. Nadziejko C, Fang K, Chen LC, Cohen B, Karpatkin M, Nadas A: Effect of concentrated ambient particulate matter on blood coagulation parameters in rats. Res Rep Health Eff Inst 2002, , 111: 7-29, discussion 3128.

7. Barregard L, Sallsten G, Gustafson P, Andersson L, Johansson L, Basu S, Stigendal $L$ : Experimental exposure to wood-smoke particles in healthy humans: effects on markers of inflammation, coagulation, and lipid peroxidation. Inhal Toxicol 2006, 18(11):845-853.

8. Brauner EV, Moller P, Barregard L, Dragsted LO, Glasius M, Wahlin P, Vinzents P, Raaschou-Nielsen O, Loft S: Exposure to ambient concentrations of particulate air pollution does not influence vascular function or inflammatory pathways in young healthy individuals. Part Fibre Toxicol 2008, 5:13.

9. Chuang KJ, Chan CC, Su TC, Lee CT, Tang CS: The effect of urban air pollution on inflammation, oxidative stress, coagulation, and autonomic dysfunction in young adults. Am J Respir Crit Care Med 2007, 176(4):370-376.

10. Riediker M, Devlin RB, Griggs TR, Herbst MC, Bromberg PA, Williams RW, Cascio WE: Cardiovascular effects in patrol officers are associated with fine particulate matter from brake wear and engine emissions. Part Fibre Toxicol 2004, 1(1):2.

11. Schneider A, Neas LM, Graff DW, Herbst MC, Cascio WE, Schmitt MT, Buse JB, Peters A, Devlin RB: Association of cardiac and vascular changes with ambient PM2.5 in diabetic individuals. Part Fibre Toxicol 2010, 7:14.

12. Khandoga A, Stampfl A, Takenaka S, Schulz H, Radykewicz R, Kreyling W, Krombach F: Ultrafine particles exert prothrombotic but not inflammatory effects on the hepatic microcirculation in healthy mice in vivo. Circulation 2004, 109(10):1320-1325.

13. Kodavanti UP, Schladweiler MC, Ledbetter AD, Hauser R, Christiani DC, McGee J, Richards JR, Costa DL: Temporal association between pulmonary and systemic effects of particulate matter in healthy and cardiovascular compromised rats. J Toxicol Environ Health A 2002, 65(20):1545-1569.

14. Nemmar A, Hoylaerts MF, Hoet PH, Nemery B: Possible mechanisms of the cardiovascular effects of inhaled particles: systemic translocation and prothrombotic effects. Toxicol Lett 2004, 149(1-3):243-253.

15. Nemmar A, Nemery B, Hoet PH, Vermylen J, Hoylaerts MF: Pulmonary inflammation and thrombogenicity caused by diesel particles in hamsters: role of histamine. Am J Respir Crit Care Med 2003, 168(11):1366-1372

16. Upadhyay S, Stoeger T, Harder V, Thomas RF, Schladweiler MC, SemmlerBehnke M, Takenaka S, Karg E, Reitmeir P, Bader M, et al: Exposure to ultrafine carbon particles at levels below detectable pulmonary inflammation affects cardiovascular performance in spontaneously hypertensive rats. Part Fibre Toxicol 2008, 5:19.
17. Levi M: The coagulant response in sepsis and inflammation. Hamostaseologie 2010, 30(1):10-12, 14-16.

doi:10.1186/1743-8977-8-12

Cite this article as: Kilinç et al:: The procoagulant effects of fine particulate matter in vivo. Particle and Fibre Toxicology 2011 8:12.

\section{Submit your next manuscript to BioMed Central and take full advantage of:}

- Convenient online submission

- Thorough peer review

- No space constraints or color figure charges

- Immediate publication on acceptance

- Inclusion in PubMed, CAS, Scopus and Google Scholar

- Research which is freely available for redistribution

Submit your manuscript at www.biomedcentral.com/submit
Biomed Central 